ECOLOGICA, Vol. 28, No 102 (2021), 301-308

https://doi.org/10.18485/ecologica.2021.28.102.23

Originalni naučni rad

UDC: 614.72:[616.98:578.834](497.11Beograd)

614.72:[616.98:578.834](497.15Sarajevo)

\title{
Aerozagađenje u vreme početka COVID-19 pandemije: analiza emisija u Beogradu i Sarajevu
}

\section{Air pollution in the beginning of the COVID-19 pandemic: analysis of emissions in Belgrade and Sarajevo}

\author{
Nataša Bojković ${ }^{1}$, Tanja Živojinović ${ }^{2 *}$, Nikola Zornić ${ }^{3}$ \\ 1,2Univerzitet u Beogradu, Saobraćajni fakultet, Beograd, Srbija / \\ University of Belgrade, Faculty of Transport and Traffic Engineering, Belgrade, Serbia \\ 3Univerzitet u Beogradu, Fakultet organizacionih nauka, Beograd, Srbija / \\ University of Belgrade, Faculty of Organisational Sciences, Belgrade, Serbia \\ ${ }^{*}$ Autor za prepisku / Corresponding author
}

Rad primljen / Received: 18.12.2020, Rad prihvaćen / Accepted: 14.05.2021.

Sažetak: Vanredna situacija prouzrokovana virusom COVID-19 dovela je, očekivano do smanjenja aerozagađenja u mnogim delovima sveta. Istraživanja ukazuju da se u zavisnosti od stepena restrikcije društveno-ekonomskih aktivnosti, ali i vrste polutanata, beleže različiti ishodi - od značajnog poboljšanja kvaliteta vazduha do simboličnih smanjenja emisija zagađivača. U ovom radu prikazano je prisustvo nekoliko najvećih zagađivača u godini pandemije i izvršena uporedna analiza u odnosu na prosečne vrednosti iz prethodnog petogodišnjeg perioda. Istraživanjem su obuhvaćena dva grada regiona jugoistočne Evrope Beograd i Sarajevo. Rezultati ovog rada svedoče o tome da su na kvalitet vazduha, pored restrikcija kretanja usled proglašene pandemije, uticaj imali i drugi činioci različitog porekla pre svega vrsta goriva za grejanje domaćinstava i industrijska postrojenja.

Ključne reči: SARS-CoV-2, kvalitet vazduha, zagađivači, urbana sredina.

\begin{abstract}
The emergency caused by the COVID-19 has led to a reduction in air pollution in many parts of the world. Research indicates that depending on the degree of restriction of socio-economic activities, but also the type of pollutants, different outcomes are recorded - from a significant improvement in air quality to symbolic reductions in pollutant emissions. This paper presents several significant polluters in the year of the pandemic and performed a comparative analysis concerning the average values from the previous five - year period. The research covered two cities in the region of Southeast Europe - Belgrade and Sarajevo. The results of this paper testify that air quality, in addition to restrictions on movement due to the pandemic, was also influenced by other sources, primarily the type of fuel for households heating and industrial plants.
\end{abstract}

Keywords: SARS-CoV-2, air quality, pollutants, urban area.

${ }^{1}$ orcid.org/0000-0002-9291-8999, e-mail: n.bojkovic@sf.bg.ac.rs

2orcid.org/0000-0003-0015-1637, e-mail: t.zivojinovic@sf.bg.ac.rs

2orcid.org/0000-0002-3597-0627, e-mail: nikola.zornic@fon.bg.ac.rs 


\section{UVOD / INTRODUCTION}

Zagađivači vazduha predstavljaju stalan i ozbiljan rizik za kardiovaskularni i respiratorni sistem, pa se aerozagađenje danas smatra najvećom pojedinačnom ekološkom pretnjom ljudskom zdravlju, posebno u urbanim područjima. Prema procenama Svetske zdravstvene organizacije, emisije zagađivača iznad dozvoljenih vrednosti, u svetu odnose oko 7 miliona života godišnje, pri čemu ekonomski manje razvijene zemlje, usled nedovoljnih investicija u razvoj čistijih tehnologija, beleže veću izloženost svoje populacije aerozagađenju. Na evropskom prostoru, prema podacima Evropske agencije za zaštitu životne sredine iz 2018. godine, procenjuje se da se 379.000 smrtnih slučajeva u državama članicama EU može pripisati lošem kvalitetu vazduha. Najveću zabrinutost međutim izazivaju pokazatelji evropskih država van EU, koje imaju značajno lošiju statistiku. U odnosu na emisije suspendovanih čestica $\mathrm{PM}_{2.5}$, azotnih oksida i ozona, a prema broju stanovnika, zemlje centralne i istočne Evrope - Srbija, Bugarska, Albanija, Bosna i Hercegovina i Severna Makedonija prednjače u pogledu smanjenja životnog veka usled zagađenja ovim polutantima (EEA, 2019).

U vreme pandemije COVID-19, pitanje aerozagađenja još je više aktuelizovano zbog moguće povezanosti sa smrtnim ishodima ili težim oblicima bolesti. Ne manje važno pitanje jeste uticaj mera za suzbijanje epidemije na antropogene emisije i kvalitet vazduha. Kada je reč o ovoj temi, postoji veliki broj publikovanih studija koje su uglavnom rađene za epidemiološki teže pogođena područja. Istraživanja koja su sprovedena u 44 kineska grada pokazala su da je u periodu zatvaranja došlo do značajnog smanjenja emisija primarnih polutanata $\mathrm{SO}_{2}, \mathrm{PM}_{2.5}, \mathrm{PM}_{10}, \mathrm{NO}_{2} \mathrm{i}$ CO u rasponu od oko 5 do $25 \%$, pri čemu najveća smanjenja beleže $\mathrm{PM}_{10}$ i NO 2 . To je i očekivano budući da se ovi polutanti u velikoj meri generišu usled transportnih aktivnosti koje su pretrpele velike restrikcije (Bao, Zhang, 2020). S druge strane, studija koja je sprovedena u regionu Lombardije ukazuje na značajna smanjenja samo jednog polutanta - $\mathrm{NO}_{2}$, dok za ostale nema značajnih razlika u odnosu na prethodni period. To se pripisuje kako meteorološkim uslovima u posmatranom periodu, tako i kompleksnim atmosferskim fizičkim i hemijskim procesima koji su nezavisni od mera ograničenja kretanja (Cameletti, 2020). Studija koja je obuhvatila 11 najvećih španskih gradova je ukazala na smanjenje emisija $\mathrm{NO}_{2}, \mathrm{CO}, \mathrm{SO}_{2}$, i $\mathrm{PM}_{10}$, ali i na porast koncentracije prizemnog ozona $\mathrm{O}_{3}$. Pokazalo se i da je jednomesečno trajanje ograničenja kretanja nedovoljno dug period za osetnije poboljšanje kvaliteta vazduha (Briz-Redón et al., 2021). Smanjenja primarnih polutanata $\mathrm{PM}_{2.5}, \mathrm{NO}_{2}, \mathrm{CO}$, zabeležena su i u studiji indij- skih gradova, dok je ustanovljeno da nije bilo značajnijih promena emisija $\mathrm{SO}_{2}$ pre i nakon primene restriktivnih epidemioloških mera (Srivastava et al., 2020). Istraživanje koje je sprovedeno u britanskim gradovima ukazalo je da su se vrednosti $\mathrm{SO}_{2}$ čak značajno uvećale - udvostručile, nivoi $\mathrm{O}_{3}$ uvećali za oko $10 \%$, dok $\mathrm{NO}_{2}$ beleži značajan pad od oko $50 \%$. Ovi rezultati se objašnjavaju meteorološkim uslovima (Higham et al., 2021). Iz navedenih, kao i drugih istraživanja, nesumnjivo i očekivano se zaključuje da je u periodu suspenzije društvenih i ekonomskih aktivnosti privremeno došlo do izvesnog poboljšanja kvaliteta vazduha.

\section{MATERIJALI I METODE / MATERIALS AND METHODS}

U ovom radu su prikazane promene nivoa aerozagađivača u dve prestonice država regiona Zapadnog Balkana - Beogradu i Sarajevu. Korišćeni su podaci World Air Quality Index projekta dostupni za preko 380 svetskih gradova. Izvršena je uporedna analiza prosečnih mesečnih nivoa emisija iz prethodnog petogodišnjeg perioda, kao i mesečnih emisija za 2019. i 2020. godinu. S ciljem analize uticaja mera restrikcije kretanja i drugih ograničenja usled proglašene epidemije na kvalitet vazduha posmatran je period prve polovine godina. Cilj rada je da se bolje sagledaju trendovi emisija najznačajnijih zagađivača u analiziranim gradovima. Na ovaj način daje se uvid u uticaj pandemije, odnosno epidemioloških mera na kvalitet vazduha u regionu Zapadnog Balkana, čime se doprinosi ovom globalno aktuelnom istraživačkom pitanju.

\section{REZULTATI I DISKUSIJA / RESULTS AND DISCUSSION}

U narednom odeljku dato je stanje kvaliteta vazduha u predmetnim gradovima - Beogradu i Sarajevu. Pregled restriktivnih mera koje su obeležile početak epidemije COVID-19, a koje mogu imati potencijalni uticaj na kvalitet vazduha u Beogradu i Sarajevu dat je u drugom odeljku ovog poglavlja. Treći odeljak analizira promene emisija nekoliko najvećih zagađivača u godini pandemije i daje uporednu analizu u odnosu na prosečne vrednosti iz prethodne godine (2019), kao i prethodnog petogodišnjeg perioda (2015-2019).

\subsection{Stanje kvaliteta vazduha u Beogradu i Sarajevu} / State of air quality in Belgrade and Sarajevo

Značajan deo snabdevanja energijom zemalja Zapadnog Balkana čini ugalj, čije sagorevanje je najveći pojedinačni izvor zagađenja vazduha. Države članice EU su, kao potpisnice Pariskog klimatskog sporazuma, posvećene razvoju čistih tehnologija za proizvodnju energije i većina je označila kraj 
"ere uglja". Tako je, na primer, prema podacima evropskih energetskih analitičara u 2019. godini, upotreba uglja za proizvodnju električne energije smanjena za rekordnih $24 \%$. Stopa tranzicije ka čistijoj energiji u zemljama Zapadnog Balkana je još uvek zanemarljiva iako je to jedan od ključnih uslova pridruživanja EU. U Srbiji kao i u Bosni i Hercegovini, elektrane mahom koriste ugalj slabijeg kvaliteta predviđen za industrijska postrojenja, a neefikasan u procesu proizvodnje električne energije. Na području Balkana se nalazi čak 7 od 10 najviše zagađujućih termoelektrana na ugalj u Evropi (Awe et al., 2019). Lignit, koji je dobro poznat uzročnik emisija sumpor-dioksida, azotnih oksida, suspendovanih čestica ali i ugljen-dioksida, čini okosnicu proizvodnje električne energije u termoelektranama. Najveći zagađivači vazduha su energetika, industrija i saobraćaj, pri čemu je kada je reč o Srbiji, energetski sektor dominantan emitent sumpor-dioksida (95\% ukupnih emisija) i azotnih oksida (više od 50\% ukupnih emisija) (Fiskalni savet RS, 2019).

Prema poslednjem izveštaju Agencije za zaštitu životne sredine Republike Srbije, za 2019. godinu, grad Beograd je bio prekomerno zagađen usled prekoračenja dnevnih graničnih vrednosti pojedinih emisija, pri čemu su dominantan uticaj imale suspendovane čestice $\mathrm{PM}_{10}$ koje su se najčešće pojavljivale iznad dozvoljenih okvira (Lekić, Perunović Đulić, 2020). Slična je situacija i u prethodnom periodu, od 2015-2019. godine kada je prekomerno zagađenje bilo uslovljeno povećanom koncentracijom polutanata $\mathrm{PM}_{10}, \mathrm{PM}_{2.5}$ i NO 2 . Karakteristično je da je 2015. godine povećana koncentracija $\mathrm{PM}_{10}$ bila čak 101 dan (WHO, 2019). Kada je reč o potencijalno najopasnijem polutantu $\mathrm{PM}_{2.5}$, prema izveštaju o kvalitetu vazduha u gradovima širom sveta za 2019. godinu (IQAir, 2021), gradovi Beograd i Sarajevo spadaju među zagađenije gradove Evrope i sveta sa koncentracijama $\mathrm{PM}_{2.5}$ koje su više od dva (Beograd) odnosno tri (Sarajevo) puta veće od graničnih godišnjih vrednosti koje propisuje Svetska zdravstvena organizacija. Pored individualnih ložišta, Sarajevo - poznat i kao grad u kotlini, ima i problem nedovoljnog strujanja vazduha što je dobrim delom posledica neplanske gradnje.

Kao posledica procenjuje se da je u gradu Beogradu blizu 1800 prevremenih smrtnih slučajeva godišnje prouzrokovano povećanim koncentracijamaPM 2.5. Smanjenje ovog polutanta za $10 \mu \mathrm{g} / \mathrm{m}^{3}$ bi ovaj broj prepolovilo, dok bi smanjenje od 20 $\mu \mathrm{g} / \mathrm{m}^{3}$ sasvim isključilo smrtne ishode (WHO, 2019). Prema izveštaju o stanju kvaliteta vazduha u Bosni i Hercegovini (Awe et al., 2019), povećane koncentracije $\mathrm{PM}_{2.5}$ uzročnici su 3300 smrtnih ishoda u Bosni i Hercegovini, od čega najveći udeo imaju gradovi Sarajevo i Banja Luka.
2.2. Početak epidemije Covid-19 i inicijalne epidemiološke mere u Beogradu i Sarajevu / The beginning of the Covid-19 epidemic and the initial epidemiological measures in Belgrade and Sarajevo

Krajem decembra 2019. godine kineske vlasti su prijavile Svetskoj zdravstvenoj organizaciji (engl. World Health Organization, u daljem tekstu WHO) pojavu novog soja korona virusa koji je uzrokovao pojavu bolesti u gradu Vuhanu (Kina). Suočena sa brzinom širenja i pretećim globalnim posledicama, WHO je 11. marta 2020. godine proglasila pandemiju izazvanu korona virusom SARS-CoV-2. Prema podacima dostupnim na sajtu WHO na dan 12.05. 2021. u svetu je bilo potvrđeno 159.319.384 slučajeva bolesti COVID-19, dok je broj preminulih od posledica zaraze bio 3.311.780 (WHO, 2021).

U prvim danima 2020. godine virus je već bio zastupljen na evropskom kontinentu, sa prvim slučajevima zaraze u Francuskoj. Potvrda prvih slučajeva bolesti COVID-19 u Srbiji evidentirana je 6. marta, a Vlada Srbije proglasila je vanredno stanje 15. marta. Od 18. marta bio je na snazi policijski čas koji je uveo restrikciju kretanja od $20.00 \mathrm{~h}$ do 05.00h za sve građane, osim za one sa posebnom dozvolom. Posle nekoliko dana policijski čas je produžen pa je zabrana bila na snazi od $17.00 \mathrm{~h}$ do 05.00h narednog dana. $U$ danima vikenda i tokom Uskršnjih (17.04-21.04.) i prvomajskih praznika (30.04-02.05.) važila je potpuna restrikcija kretanja. U Srbiji je 7. maja 2020. godine ukinuto vanredno stanje. U periodu njegovog trajanja došlo je do obustave javnog gradskog, međugradskog i međunarodnog saobraćaja (uključujući i vazdušni saobraćaj). Privremeno je došlo do zatvaranja obdaništa, škola, fakulteta, tržnih i sportskih centara, pijaca, itd. Važile su preporuke da zaposleni u svim delatnostima, gde je to moguće, pređu na rad od kuće. Dozvolu da rade u ovom periodu imale su samo prodavnice prehrane, apoteke, benzinske pumpe i medicinske ustanove.

Prvi slučajevi zaraze virusom SARS-CoV-2 u Bosni i Hercegovini zabeleženi su, takođe, početkom marta 2020. godine u Banja Luci. Prvi zaraženi u Sarajevu evidentirani su 20. marta 2020. godine. Shodno tome, već krajem prve polovine marta došlo je do zatvaranja škola i fakulteta. Nedugo zatim izdate su naredbe $u$ vezi sa privremenim zatvaranjem ugostiteljskih objekata, objekata kulturnog sadržaja, sportskih centara i sl, kao i naredba o prekidu funkcionisanja javnog prevoza. Od 22. marta nastupio je policijski čas sa zabranom kretanja građana u periodu 18.00-05.00h. Nekoliko dana kasnije, 29. marta policijski čas je skraćen na period 20.00-05.00h. Ovakve mere restrikcije kretanja u Federaciji Bosne i Hercegovine trajale su do 24. 
aprila 2020.godine. U ovom periodu, kretanje je bilo omogućeno samo licima/vozilima sa posebnom dozvolom i vozilima hitnih službi (Reuters, 2021).

Iz navedenog se može zaključiti da je sprečavanje širenja novog soja korona virusa postalo državni prioritet i da je dovelo do brojnih ograničenja u svakodnevnom životu i radu. Primena inicijalnih mera uslovljenih širenjem bolesti COVID-19 u Beogradu i Sarajevu imala je za cilj da spreči fizičke kontakte i uspori širenje virusa. Ipak, iskustva drugih gradova posvedočila su o tome da je korona virus imao i druge efekte pri čemu je jedan od najznačajnijih uticaj na kvalitet vazduha. Upravo je to poslužilo kao motiv za istraživanje kvaliteta vazduha u Beogradu i Sarajevu u vreme inicijalnih COVID-19 mera.

\subsection{Covid-19 i emisije polutanata / Covid-19 and pollutant emissions}

U Tabelama 1 i 2 prikazane su prosečne vrednosti najznačajnijih polutanata u Beogradu i Sarajevu, respektivno, za prvu polovinu 2020. i 2019. godine, kao i prosečne vrednosti polutanata u prethodnom petogodišnjem periodu. Na Grafikonima $1 \mathrm{i}$ 2 su označene promene prosečnih i maksimalnih dnevnih emisija za gradove Beograd i Sarajevo, za period 15.03-15.04.2020. godine, iz razloga što su u ovom periodu u oba grada stupile na snagu oštre epidemiološke mere. Usled nedostajućih podataka u posmatranom periodu izostavljen je prikaz promena emisija $\mathrm{CO}$ za oba grada.

Kada je reč o Beogradu, rezultati ukazuju da je sa izuzetkom nekoliko dana, došlo do značajnog pada emisija $\mathrm{NO}_{2}$ u 2020. godini i to kako prosečnih, tako i maksimalnih vrednosti. Ovo smanjenje je iznosilo oko 50\% (videti Tabelu 1). Ovaj trend je još izraženiji u Sarajevu gde su i maksimalne dnevne i prosečne vrednosti tokom čitavog posmatranog perioda bile značajno manje u odnosu na prethodnu godinu (sa padom od više od $57 \%$ u mesecu aprilu).

Emisije prizemnog ozona su se povećale u Beogradu, dok su se u Sarajevu smanjile, što govori o nedovoljno izraženoj korelaciji između restrikcije kretanja i nivoa prisustva ovog polutanta. Ovo je u skladu i sa prethodno navedenim nalazima iz literature (videti uvodni deo rada). Emisije sumpordioksida imaju trend rasta u odnosu na prethodnu godinu i u Beogradu i u Sarajevu. Iz toga zaključujemo da inicijalne epidemiološke mere nisu imale uticaja na ovaj polutant. Ovakvi nalazi nisu neočekivani budući da su energetska postrojenja kao glavni izvori ovih emisija radila u punom kapacitetu tokom trajanja mera ograničenja.

Kada tumačimo nivoe emisija suspendovanih uočava se postojanje prekoračenja dozvoljenih vrednosti emisija (označeno crvenim isprekidanim linijama na grafikonima 1 i 2, prikazi označeni kao c i d), što je u slučaju $\mathrm{PM}_{10}$ sporadično, ali je prekoračenje $\mathrm{PM}_{2.5}$ daleko učestalije za maksimalne dnevne vrednosti u analiziranom periodu. Ovde se mogu uočiti i razlike u posmatranim gradovima, posebno kada se osvrnemo na prosečne vrednosti u 2020. godini i vrednosti iz prethodnog petogodišnjeg perioda. U Sarajevu se uočava da je u posmatranim mesecima godine pandemije nivo emisija $\mathrm{PM}_{2.5}$ bio značajno manji u odnosu na protekli period, dok je u Beogradu suprotno očekivanjima zabeležen rast u odnosu na isti period, kao i veći broj dnevnih prekoračenja dozvoljenih nivoa prisustva ovih čestica.

$\mathrm{Na}$ osnovu predstavljenih rezultata, može se zaključiti da se nivo smanjenja emisija ne može dovesti u jaku korelaciju sa vrstom, opsegom i trajanjem restriktivnih mera. Izvesna zavisnost se može uočiti samo kod azotnih oksida koji velikim delom potiču iz drumskog saobraćaja koji je u ovom periodu bio znatno manjeg obima. Na prisustvo ostalih polutanata uticali su brojni faktori nezavisni od primenjenih mera, poput meteoroloških uslova, lokacije mernih stanica (prometne saobraćajnice ili stambene zone), kao i kompleksnih hemijskih reakcija koje proizvode polutante.

\section{ZAKLJUČAK / CONCLUSION}

Rezultati ovog rada svedoče o tome da su na nivoe prisustva različitih zagađivača vazduha, pored restrikcija kretanja usled proglašene pandemije, uticaj imali i drugi činioci različitog porekla pre svega vrsta goriva za grejanje domaćinstava i industrijska postrojenja. Razume se da će za dugoročno poboljšanje kvaliteta vazduha od vitalnog značaja biti investicije u termoenergetska postrojenja, odnosno njihovo odsumporavanje, denitrifikacija i otprašivanje dimnih gasova. Kako se ističe i u izveštaju Fiskalnog saveta Republike Srbije (Fiskalni savet RS, 2019), ulaganje u nove tehnologije biće ne samo ekološka, već i ekonomska neminovnost, kako zbog ograničenih rezervi uglja, tako i zbog taksi na emisije ugljendioksida, čime bi se ugrozilo dalje poslovanje elektroenergetskog sistema zemlje.

\section{Zahvalnica / Acknowledgement}

Ovaj tekst je rezultat rada na projektu pod evidencionim brojem TR36022: "Upravljanje kritičnom infrastrukturom za održivi razvoj u poštanskom, komunikacionom i železničkom sektoru Republike Srbije", koji se realizuje uz finansijsku podršku Ministarstva prosvete, nauke i tehnološkog razvoja Republike Srbije. 

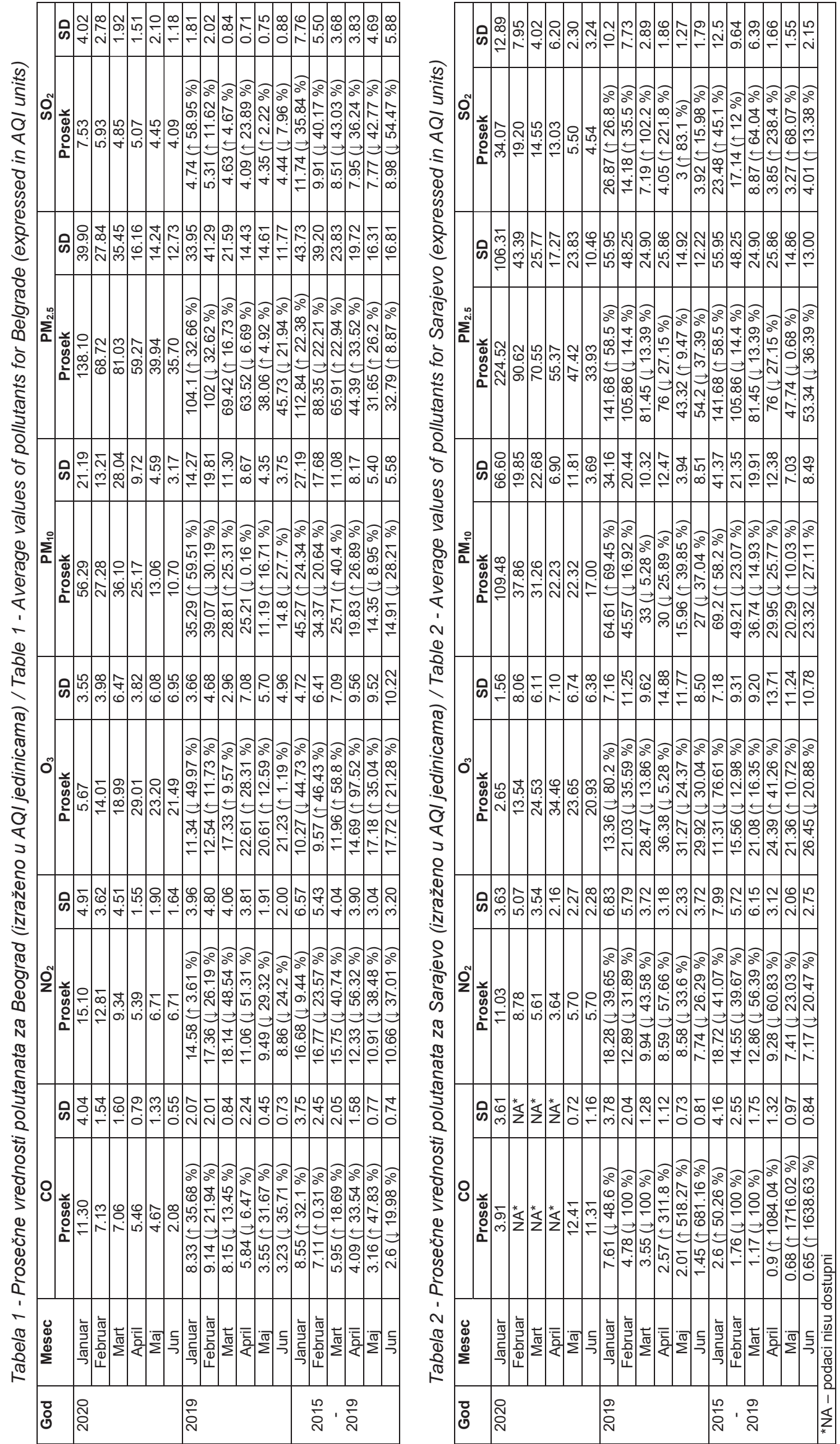


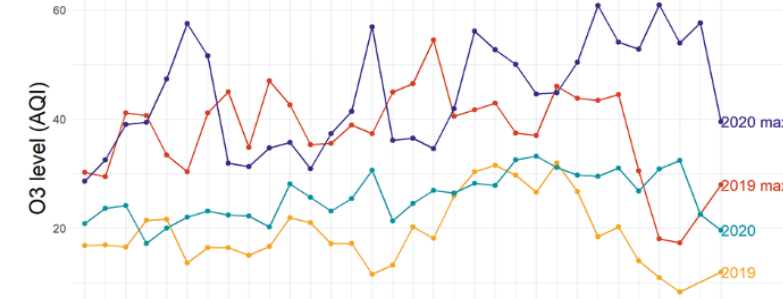

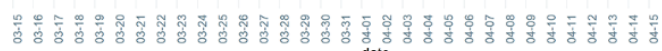

a)

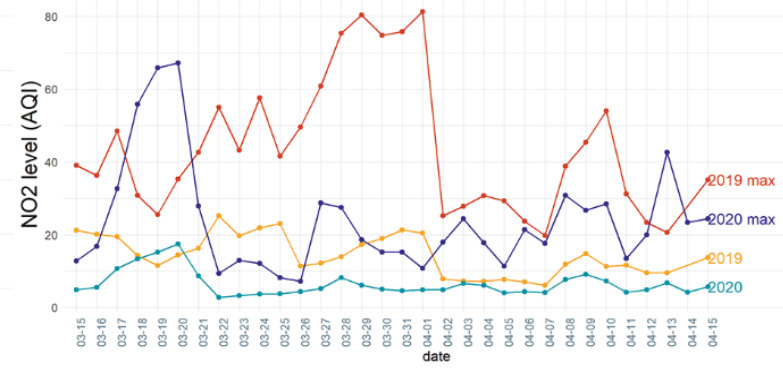

b)

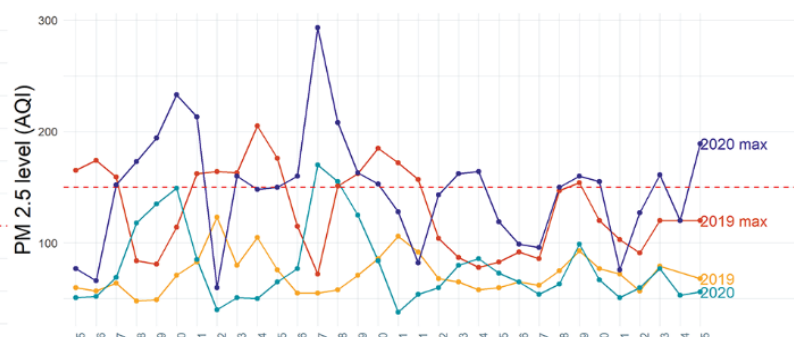

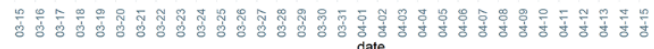

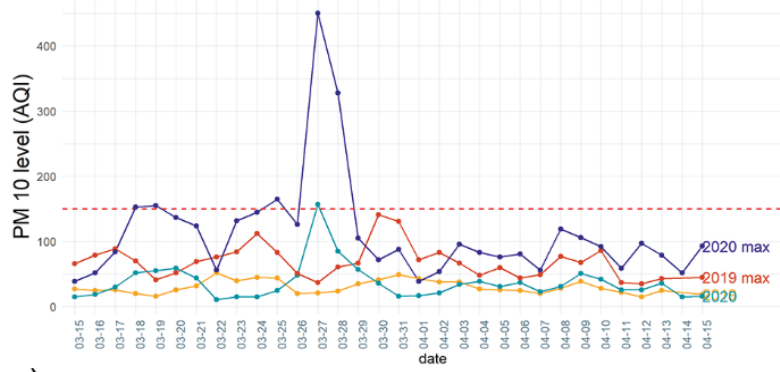

c) d)

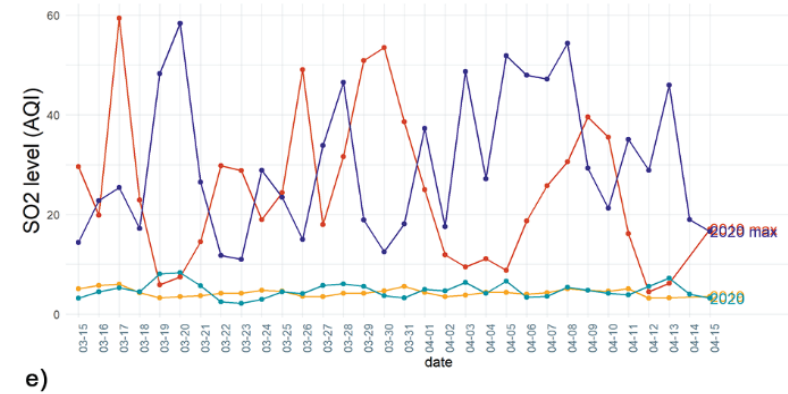

Grafikon 1 - Prosečne i maksimalne dnevne emisije polutanata u Beogradu za period 15.03-15.04.2020. Graph 1 - Average and maximum daily emissions of pollutants in Belgrade (15 th March - 15 ${ }^{\text {th }}$ April 2020) 


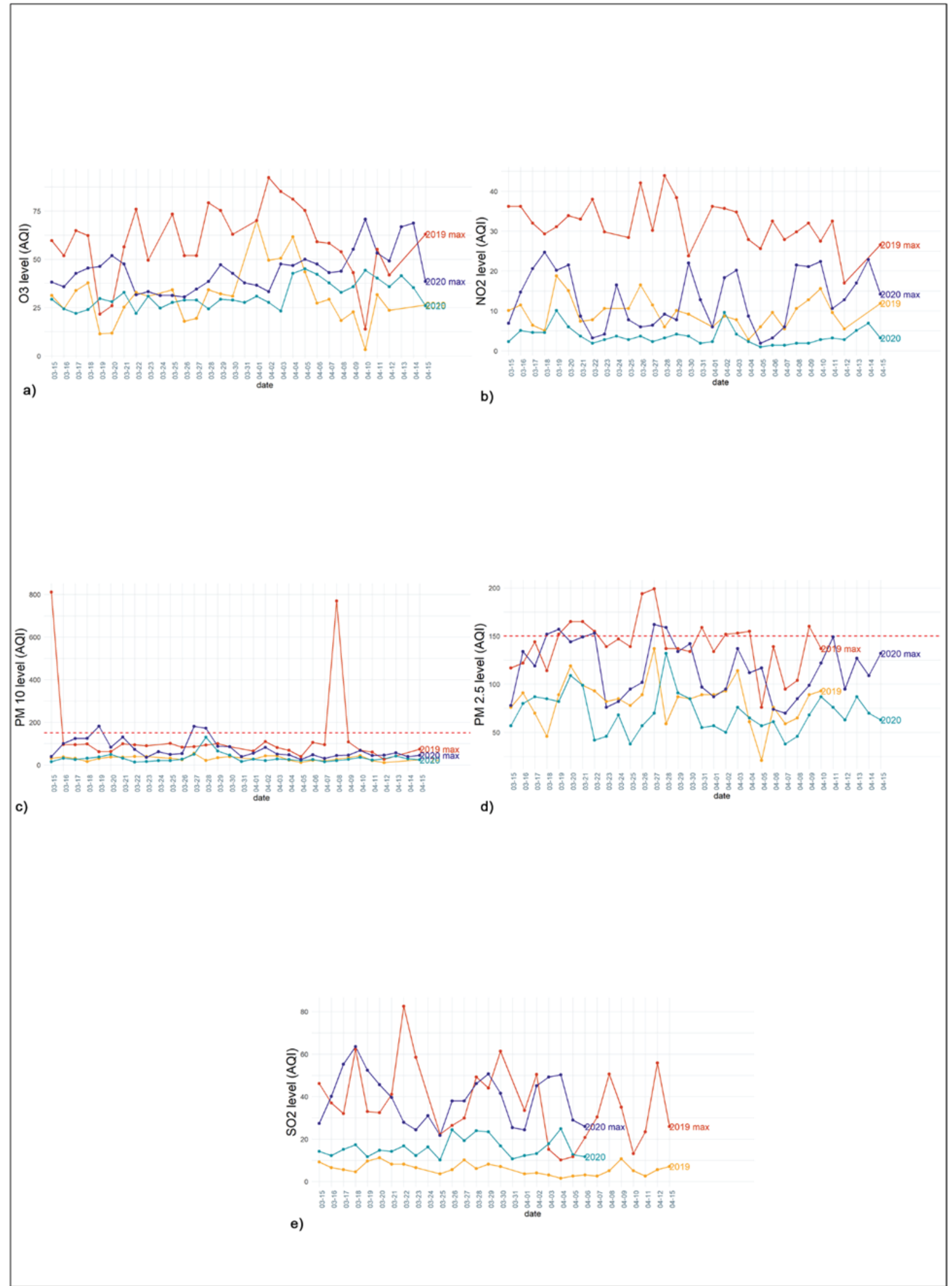

Grafikon 2 - Prosečne i maksimalne dnevne emisije polutanata u Sarajevu za period 15.03-15.04.2020.

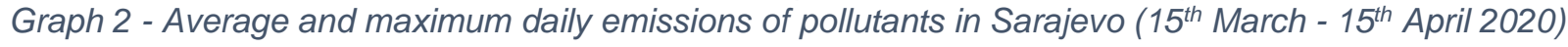




\section{LITERATURA / REFERENCES}

[1] Awe, Y. A., Murisić, M., Kreso Beslagić, E., Rinnerberger, N., Oguz Kuntasal, O., Brody, M. S., Golub, S., Enriquez, S., Paranos, D., \& Colovic-Daul, M. (2019). Air pollution management in Bosnia and Herzegovina. World Bank. Dostupno na https://documents.worldbank. org/en/publication/documentsreports/documentdetail/11728157651511158 4/air-quality-management-in-bosnia-andherzegovina (pristupljeno 30.03.2021.)

[2] Bao, R., \& Zhang, A. (2020). Does lockdown reduce air pollution? Evidence from 44 cities in northern China. Science of the Total Environment, 731, 139052.

[3] Briz-Redón, Á., Belenguer-Sapiña, C., \& Serrano-Aroca, Á. (2021). Changes in air pollution during COVID-19 lockdown in Spain: a multicity study. Journal of Environmental Sciences, 101, 16-26.

[4] EEA Report. Air quality in Europe - 2019, No 10/2019. Dostupno na Air quality in Europe 2019 - European Environment Agency (europa.eu) (pristupljeno 23.03.2021.)

[5] Cameletti, M. (2020). The Effect of Corona Virus Lockdown on Air Pollution: Evidence from the City of Brescia in Lombardia Region (Italy). Atmospheric Environment, 239, 117794.

[6] Fiskalni savet Republike Srbije (2019). Analiza poslovanja i preporuke za reforme i povećanje investicija EPS-a. Dostupno na http://www.fiskalnisavet.rs/analize-stavovipredlozi.php (pristupljeno 25.03.2021.)
[7] Higham, J. E., Ramírez, C. A., Green, M. A., \& Morse, A. P. (2021). UK COVID-19 lockdown: 100 days of air pollution reduction?. Air Quality, Atmosphere \& Health, 14(3), pp. 325-332.

[8] IQAir (2021). World Air Quality Report 2020. Dostupno na https://www.iqair.com/world-airquality-report (pristupljeno 17.03.2021.)

[9] Lekić, D., Perunović Đulić, T. (2020). Izveštaj o stanju životne sredine u Republici Srbiji za 2019. Beograd: Ministarstvo zaštite životne sredine - Agencija za zaštitu životne sredine.

[10] Reuters COVID-19 Global Tracker (2021). Dostupno na Bosnia and Herzegovina: the latest coronavirus counts, charts and maps (reuters.com) (pristupljeno 29.03.2021.)

[11] Srivastava, S., Kumar, A., Bauddh, K., Gautam, A. S., \& Kumar, S. (2020). 21-Day lockdown in India dramatically reduced air pollution indices in Lucknow and New Delhi, India. Bulletin of environmental contamination and toxicology, 105, pp. 9-17.

[12] World's Air Pollution: Real-time Air Quality Index (waqi.info).

[13] World Health Organization - Regional Office for Europe (2019). Health impact of ambient air pollution in Serbia: a call to action. Dostupno na https://www.euro.who.int/en/countries/serbia/p ublications/health-impact-of-ambient-airpollution-in-serbia-a-call-to-action-2019 (pristupljeno 15.03.2021.)

[14] World Health Organization (2021). Dostupno na https://www.who.int/emergencies/diseases/no vel-coronavirus-2019 (pristupljeno 12.05.2021) 